\title{
Применение теплой апертурной диафрагмы в охлаждаемых малоформатных матричных фотоприёмниках
}

\author{
П.П. Добровольский, И.И. Кремис, С.В. Хрящев, А.Р. Новоселов, С.М. Чурилов \\ Филиал ИФП СО РАН «КТИПМ», 630090, г.Новосибирск, пр-кт Ак.Лаврентьева, 2/1 \\ Тел. (383) 330-97-49, эл.nочта: porfir@ngs.ru
}

DOI 10.34077/RCSP2021-153

Численным моделированием и экспериментально исследованы конструкции теплой (неохлаждаемой) апертурной диафрагмы в газонаполненном криостате с матричным фотоприёмником (МФ), чувствительным в инфракрасном спектральном диапазоне. Показано, что при применении выбранной конструкции теплой апертурной диафрагмы, матричный фотоприёмник форматом 384х288 пикселей охлаждается жидким азотом до рабочих температур ( 85 К) за время менее чем 40 сек., а дроссельным микроохладителем -за 15 сек. с сохранением стандартной чувствительности фотоприёмников на основе структур кадмий-ртуть-теллур (КРТ).

При использовании многоэлементных фотоприёмников увеличивается масса охлаждаемых деталей и, следовательно, увеличивается время охлаждения таких фотоприёмников до рабочих температур. Для быстрого охлаждения фотоприемников используют газонаполненные криостаты. Они значительно проще в изготовлении, чем вакуумные криостаты, однако обладают большими теплопритоками. Для компенсации этого недостатка используют дроссельные системы охлаждения с избыточной хладопроизводительностью. В этом случае большие теплопритоки не влияют на время охлаждение фотоприёмника. Кроме самого МФ в криостат устанавливается апертурная диафрагма сложной конструкции для уменьшения паразитного фона. Охлаждение составных апертурных диафрагм увеличивает время выхода МФ на рабочий режим так как охлаждение диафрагмы осуществляется от пьедестала, на котором расположен МФ. Если разорвать тепловой контакт внутри сложной аппертурной диафрагмы и не охлаждать всю диафрагму, то время выхода на рабочий режим ФПУ сократится - такие диафрагмы можно назвать «теплыми».

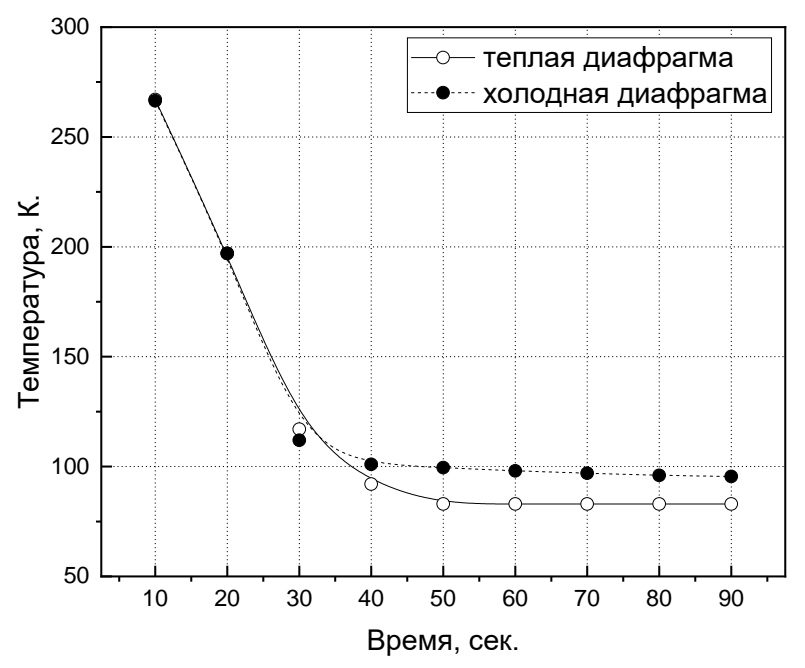

Рис 1. Результаты сравнения времени выхода МФ в газонаполненном криостате, охлаждаемым жидким азотом, с холодной (стандартная конструкция диафрагмы) и теплой апертурной диафрагмы.

Предложена конструкция теплой диафрагмы, для которой фон отражённых от внутренних поверхностей диафрагмы лучей минимален для малоформатного МФ. Применение теплой диафрагмы оптимальной конструкции в ФПУ уменьшает время выхода МФ на рабочий режим (85 К) с 1 мин. 30 сек. (холодная диафрагма) до 40 сек. 